\title{
11. DATA REPORT: INTERLABORATORY COMPARISON OF SEDIMENT GRAIN-SIZING TECHNIQUES: DATA FROM AMAZON FAN UPPER LEVEE COMPLEX SEDIMENTS ${ }^{1}$
}

\author{
A. Cramp, ${ }^{2}$ S.V. Lee, ${ }^{2}$ J. Herniman, ${ }^{2}$ R.N. Hiscott, ${ }^{3}$ P.L. Manley, ${ }^{4}$ D.J.W. Piper, ${ }^{5}$ \\ M. Deptuck, ${ }^{5}$ S.K. Johnston, ${ }^{5}$ and K.S. Black ${ }^{6}$
}

\begin{abstract}
It is known that variation can exist in grain-size data generated from automated sizing equipment currently in use; this is especially true for natural sediments, particularly for fine-grained marine muds. Over $98 \%$ of the sedimentary material recovered during Leg 155 consisted of fine-grained marine sediments, and since three shore-based laboratories have carried out the majority of the fine-grain-size analyses produced to date, it was deemed essential to carry out and present information on both analytical procedures and the sizing equipment used at each of the laboratories. This report presents interlaboratory comparisons carried out on identical samples using the Micromeritics SediGraph, the Coulter Counter, and the Coulter Laser system.

Results of the interlaboratory comparisons carried out on size data generated from two Micromeritics SediGraph machines are in reasonable agreement, though it is noted that high levels of dispersant concentration appear to produce biased data, especially within the very fine fraction. In addition, around $6 \phi(16 \mu \mathrm{m})$, there are significant differences between the data generated using the SediGraph as compared with the Laser and Coulter Counter systems. These deviations are attributed to the different techniques adopted by each piece of analytical equipment in determining grain size, and are in general agreement with similar studies that have compared the various sizing techniques. Over 600 grain-size analyses are presented (in CD-ROM format) for subsamples of fine-grained material recovered from sites along the Upper Levee Complex and the Amazon Channel of the Amazon Fan.
\end{abstract}

\section{BACKGROUND}

For some time it has been known that analytical equipment currently used to determine grain size and associated grain populations in research laboratories can produce variable data from identical samples (Syvitski, 1991). This is especially true for natural sediments. The problem has arisen for a number of reasons and, in some instances, can make comparison of data generated from different pieces of analytical equipment difficult. The equipment currently available utilizes different analytical techniques to determine grainsize populations; it appears that some techniques are better suited to certain machines than others. For example, current laser-sizing and Coulter-type devices are widely used in the food industry as well as in many rheological and tribological studies, whereas the Micromeritics SediGraph is used extensively for the determination of finegrained natural sediment.

Three of the most common sizing instruments currently being used to determine the grain size of natural sediments are the Micromeritics SediGraph, Coulter Counter, and a variety of laser-sizing machines (Coulter and Malvern in particular).

\section{Micromeritics SediGraph}

The SediGraph produces grain-size analyses using an X-ray absorption technique with the concentration of settling particles which decreases as a function of time (Stokes' Law). It is possible to obtain

${ }^{1}$ Flood, R.D., Piper, D.J.W., Klaus, A., and Peterson, L.C. (Eds.), 1997. Proc. ODP, Sci. Results, 155: College Station, TX (Ocean Drilling Program).

${ }^{2}$ Marine and Environmental Geosciences Research Group, Department of Earth Sciences, University of Wales Cardiff, Cardiff CF1 3YE, United Kingdom. cramp@ cardiff.ac.uk

${ }^{3}$ Department of Geology, Memorial University, St. Johns, Newfoundland, Canada.

${ }^{4}$ Department of Geology, Middlebury College, Middlebury, Vermont 05753, U.S.A.

${ }^{5}$ Atlantic Geoscience Centre, Geological Survey of Canada (Atlantic), Bedford Institute of Oceanography, P.O. Box 1006, Dartmouth, Nova Scotia B2Y 4A2, Canada.

${ }^{6}$ Gatty Marine Laboratory, St. Andrews University, St. Andrews, Scotland, United Kingdom. a range of sizes from $4.0 \phi$ to $12 \phi$, although, as in the examples presented here, a run is usually terminated before $12 \phi$ because there are some questions regarding the reliability of the SediGraph at submicron sizes $(10 \phi)$. The latter was first reported by Hendrix and Orr (1972) in one of the first reviews of automatic sizing techniques and equipment. For a detailed report of SediGraph operation, the reader is referred to Coakley and Syvitski (1991).

\section{Coulter Counter}

Electro-resistance particle size analyzers, like the widely used Coulter Counter, determine grain size by using particle suspension and aperture constriction. In this method, particles are suspended in an electrolyte solution and passed through an aperture having electrodes on each side. Particles migrate through the aperture and displace the electrolyte, increasing the resistance between electrodes. A constant current is maintained, and the resistance changes are converted to voltage signals, which are in turn amplified, analyzed, and counted. The resultant resistance changes are equated with spherical volumes via calibration experiments for the sizes being analyzed. The reader is referred to Milligan and Kranck (1991) and references cited therein for a review of the operation of electro-resistance particle size analyzers.

\section{Laser Sizing (Coulter and Malvern)}

Laser sizing utilizes the principle that grains of different sizes diffract light through different angles; a decrease in size produces an increase in diffracted angle. A lens is placed between the illuminated sample with the detector at its focal point, which focuses the undiffracted light to a point at the center of the detector. This leaves a surrounding diffraction pattern that does not vary with particle movement. Laser-sizing equipment usually has at least three lenses (63, 100 , and $300 \mathrm{~mm}$ ) with which particle size can be determined. The focal length of each lens determines the size range that can be analyzed. For example, most of the Malvern Laser systems operate with 63-, 100-, and 300-mm lenses, and the corresponding size ranges are 
1.2-118 $\mu \mathrm{m}, 1.9-188 \mu \mathrm{m}$, and 5.6-564 $\mu \mathrm{m}$. McCave et al. (1986) and Agrawal et al. (1991) provide comprehensive reviews with regard to the operation and performance of laser-diffraction sizing systems. The reader is referred to Singer et al. (1988) and, more recently, Syvitski (1991) for comprehensive reviews of current sizing equipment, operational procedure, and data evaluation.

Because a large percentage of the total sediment recovered during Leg 155 was composed of fine-grained muds, and the laboratories that undertook post-cruise sizing of these sediments used different analytical equipment and techniques, it became apparent that an interlaboratory comparison of analytical sizing equipment and procedures was an essential prerequisite to interpreting resultant grain-size data. This report provides a comparison between analytical equipment and the techniques adopted at three laboratories together with data generated from 250 subsamples taken from cores recovered along the Amazon Channel and Upper Levee Complex (ULC; Manley and Flood, 1988).

The interlaboratory comparison and database were generated using two Micromeritics SediGraph machines; one operated within the Department of Earth Sciences at the University of Wales Cardiff, United Kingdom, and the other, an identical model, run at the Department of Earth Sciences at Memorial University of Newfoundland, St. Johns, Canada. The third laboratory, the Bedford Institute of Oceanography at Halifax (BIO), Nova Scotia, Canada, used a Coulter Counter. In addition, for the purposes of intercomparison between techniques, a Coulter Laser (sizing) system operated by the Geology Department at the University of St. Andrews, Scotland, United Kingdom, was used.

\section{ANALYTICAL PROCEDURES AND EQUIPMENT Cardiff Micromeritics SediGraph}

The determination of grain-size populations was carried out using a Micromeritics SediGraph ET5100 particle-size analyzer. On removal from the plastic sampling vials, samples were placed on petri dishes and allowed to dry in an oven at $40^{\circ} \mathrm{C}$. After 2 to 3 days, the dry weight was recorded. A subsample of between 5 and $7 \mathrm{~g}$ was placed in a sample vial with a solution of $0.1 \%$ Calgon for $48 \mathrm{hr}$ (Stein, 1985). The sample was then placed on a $90-\mu \mathrm{m}$ mesh sieve and washed into a glass jar using the $0.1 \%$ Calgon solution. The $>90-$ $\mu \mathrm{m}$ fraction was washed onto a pre-weighed filter paper and dried at $40^{\circ} \mathrm{C}$ overnight. The dry weight is recorded as a percentage of the total sample weight. If the $>90-\mu \mathrm{m}$ fraction represented more than $10 \%$ of the total sample weight, then it was dry-sieved using brass sieves. The $<90-\mu \mathrm{m}$ fraction was placed in an ultrasonic water bath for $2 \mathrm{~min}$ prior to analysis and then made up to a $2 \%$ concentration by volume prior to SediGraph analysis. X-ray counts on a baseline solution of $0.1 \%$ Calgon were $\sim 75,000$ counts during analysis of the Amazon Fan samples. Typical sediment samples ran at 45,000-65,000 counts. Calibration of the machine was carried out on a regular basis using the garnet reference samples supplied by the manufacturer and an inhouse marine sediment standard. Because the settling method is particularly sensitive to fluctuations in temperature, the equipment is housed and operated in a constant temperature environment.

At Cardiff, interlaboratory comparisons were carried out on six samples (three with Memorial and three with Bedford) taken from sediment recovered during Leg 155 . These samples represent a range of grain sizes. In addition, 120 samples were run in Cardiff on samples collected from the Upper Levee Complex of the Amazon Fan. In most cases, these fine-grained samples were admixtures of sediment, many of which contained visually recognizable sand.

\section{Memorial Micromeritics SediGraph}

The grain size of all samples was determined using a Micromeritics SediGraph 5100 particle-size analyzer. The sediment, once removed from the subsample plastic cubes, was placed in a so- lution of $15 \%$ peroxide to remove organic debris, then oven dried at $40^{\circ} \mathrm{C}$ so that an accurate dry weight could be determined. After being weighed, sediment was re-suspended in $0.5 \%$ Calgon (Singer et al., 1988 ) during $15 \mathrm{~s}$ of insonification at $200-\mathrm{W}$ power provided by a Braunsonic 1510 ultrasonic probe. Resuspended samples were wetsieved through a $63-\mu \mathrm{m}$ sieve. The sand fraction $(>63 \mu \mathrm{m})$ was dried and weighed to determine its contribution to the total sample weight. The fine suspension was homogenized with a magnetic stirrer and diluted into the optimum concentration range for introduction to the SediGraph. No particular sample concentration is required for SediGraph analysis, although it is recommended that the sample reduce the radiation beam intensity, relative to background, by $13 \%-70 \%$. This is usually achieved with suspensions of $\sim 5 \%$ concentration by volume (Singer et al., 1988). Although this concentration is regarded as being very high by some authors (cf. Stein, 1985), and may, in some instances, actually hinder settling of particles, the high level of dispersant was required in order to prevent aggregates from flocculating during counting. X-ray counts on a typical baseline solution of $0.5 \%$ Calgon were about 75,000 during analysis of the Amazon Fan samples. Typical sediment samples ran at 45,000-65,000 counts.

Because the initial sample was wet-sieved at $63 \mu \mathrm{m}$, we were surprised that the first runs on the SediGraph assigned part of the sediment to the size class $63-125 \mu \mathrm{m}$. The SediGraph software bases its determination of size on values for fluid viscosity and density (these are known values at a specified operating temperature) and grain density (specified as $2.65 \mathrm{~g} / \mathrm{cm}^{3}$ for the first runs). However, Amazon Fan silts and sands contain between $5 \%$ and $15 \%$ heavy minerals (for example, hornblende with a specific gravity (SG) of 3.0-3.4, and pyroxene with SG of 3.25-3.55), so that the average grain density is higher than that of quartz. Twelve unconsolidated silt samples for which grain density was determined for Flood, Piper, Klaus, et al. (1995) gave a mean density of $2.786 \mathrm{~g} / \mathrm{cm}^{3}$, with a standard deviation of $0.05 \mathrm{~g} / \mathrm{cm}^{3}$. When all samples were replotted using an input grain density of $2.79 \mathrm{~g} / \mathrm{cm}^{3}$, reported weight percentages in the $63-125 \mu \mathrm{m}$ size class became insignificant.

The $>63-\mu \mathrm{m}$ fraction of samples that contained more than $10 \%$ sand were further analyzed over the range of 350-31 $\mu \mathrm{m}$ using the SediGraph and ethylene glycol. Both data sets (fine analysis and either a coarse analysis or the weight percent $>63 \mu \mathrm{m}$ for samples with $<10 \%$ sand) were combined in proportion to the results of wet sieving and plotted as cumulative percent on probability paper, with grainsize expressed in $\phi$ units (where $\phi$ was defined as $-\log 2 \mathrm{~d}$, and where $d$ was the grain diameter in millimeters).

Four small samples from silt laminae in Bouma Td divisions were spiked with $2 \mathrm{~g}$ of evenly sized quartz sand $(125-90 \mu \mathrm{m})$ to increase the sediment concentration. The weight percent attributed to the sand spike, having no overlap in size with the silt in the sample, was deleted from the data file before normalizing the silt component from $70 \%$ to $85 \%$, so that the shape of its plot on probability paper was similar to the shape of plots for unspiked samples. Any potential effect of modification of settling behavior of the fine particles due to the presence of sand grains in the dilute suspensions was assumed to be negligible.

In all, 123 samples were run on fine-grained material subsampled from cores taken along the Amazon Channel. These data have been referred to in Hiscott et al. (this volume) and are presented in Table 5 on CD-ROM (back pocket, this volume).

\section{Bedford Institute of Oceanography Coulter Counter}

Grain-size analyses were performed on small samples taken from core slabs sampled with a "Scripps-type" sampler. Analyses are reported by Piper and Deptuck (this volume). Analyses were made using a Coulter Counter model number TA II with sediment dispersed in a 5\% Calgon electrolyte solution.

A minimum sample size of $\sim 3 \mathrm{~mm}^{3}$ was used. The samples were put into 15-20 mL bottles and filled with the 5\% Calgon solution. The bottles were placed into $2 \mathrm{~cm}$ of water in an ultrasonic bath for 2 
to $3 \mathrm{hr}$ to disaggregate the sediment (some samples may require longer periods of time in the sonic bath to disaggregate completely).

For most natural sediments, the overall grain-size distribution is determined by running the samples through two apertures on the Coulter Counter. The normal size range of a Coulter Counter is $2 \%-$ $40 \%$ of the aperture diameter, for example, $80-4 \mu \mathrm{m}$ and $12-0.6 \mu \mathrm{m}$ for the apertures used here $(30 \mu \mathrm{m}$ and $200 \mu \mathrm{m})$. A current is applied to the electrolyte solution and the sediment particles are sucked through each aperture and classed into one of 16 grain-size categories. A particle count of 100,000 is used to get an accurate representation of the entire sample. The results are only saved if the aperture remains unclogged during the entire analysis. The $30-\mu \mathrm{m}$ aperture gives a distribution of the finer grained components of the sample. The sample solution must be filtered through a $30-\mu \mathrm{m}$ sieve to isolate the finer sediment and to avoid clogging the aperture. The $200-\mu \mathrm{m}$ aperture allows for a wider range of grain sizes to be analyzed. There is no need to filter the sample with a $200-\mu \mathrm{m}$ sieve unless the aperture is clogging. The two distributions are then merged and an "average" distribution is given. For a detailed explanation of the merging and averaging procedure adopted herein, the reader is referred to Milligan and Kranck (1991).

Replicate analyses were made from two adjacent samples in the same bed in Section 155-930C-11X-2 and from two beds in Section 155-940A-3H-4. A fourth replicate pair from Sample 155-940A$21 \mathrm{X}-2,108 \mathrm{~cm}$, were sampled laterally in homogenous sediment. In addition, four replicate pairs were run to ensure that oxidation of diagenetic iron minerals did not lead to cementation. One sample was treated in the normal manner, whereas the other was heated with sodium dithionate and sodium citrate to remove any iron oxides. In all cases, grain-size distributions were almost identical in replicate pairs.

In addition to the interlaboratory comparison, 340 samples were run using the Coulter Counter at BIO. These data represent highresolution grain-size information on overbank deposits and are discussed in Piper and Deptuck (this volume). All data generated by BIO are presented in Table 6 on CD-ROM (back pocket, this volume).

\section{St. Andrews Coulter Laser Particle Sizer}

Three samples (155-930D-6H-5, 62-65 cm (Part I), 155-930D$6 \mathrm{H}-5,62-65 \mathrm{~cm}$ (Part II), and 155-931B-12X-3, 8-110 cm) that had been analyzed using the SediGraph in Cardiff and the Coulter Counter at BIO were run on a laser-sizer (Coulter LS 1300 Laser Particle Sizer) at the Department of Geology, St. Andrews University. Samples were "digested" for $1 \mathrm{hr}$ in $30 \% \mathrm{H}_{2} \mathrm{O}_{2}$ at $60^{\circ} \mathrm{C}$, and then rinsed in distilled water and placed in storage vials in a $0.1 \%$ solution of Calgon. During analysis, samples were recirculated and continuously agitated ultrasonically in tap water within the laser sizer.

\section{INTERCOMPARISON OF GRAIN-SIZING TECHNIQUES}

\section{SediGraph Data Comparison at Cardiff and Memorial}

The data produced by the two SediGraph machines (Earth Sciences Departments at Cardiff and St. Johns) are presented in Tables 1 and 2 and in Figure 1. In addition, the correlation between each sample run on each machine is presented in Figure 2.

Two of the samples, 155-939B-6H-3, 52-54 cm (Fig. 1B), and 155-946A-1H-2, 23-25 cm (Fig. 1C), produced correlation coefficients of 0.942 and 0.991 , respectively. These correlations indicate a high degree of agreement between the two machines. Sample 155940A-4H-5, 127-130 cm (Fig. 1A) on the other hand, produced a correlation of 0.789 , which is particularly poor. The poor correlation obtained for Sample 155-940A-4H-5, 127-130 cm, may result from hindered settling velocities produced by the high concentration of dispersant used by Memorial in attempting to produce deflocculated samples for SediGraph analysis.

\section{Interlaboratory Comparison of Sizing Equipment}

The interlaboratory comparison of sizing equipment results is presented in Table 3 and Figure 3. Initially, it should be noted that the SediGraph is capable of measuring a larger range of sediment size, which, in some instances, can extend as far down as colloidal material. However, the Coulter Counter and laser systems are not designed to specifically measure this range. The SediGraph employs a settling technique, whereas the other methods extrapolate size from other predetermined parameters such as diffraction (laser). For natural sediment containing a wide range of shapes and composition, the SediGraph will resolve sedimentation diameter as opposed to a hydraulic equivalent. To overcome this problem for the more fine-grained sediments recovered from the Amazon Fan and to produce more realistic comparisons between the various pieces of equipment, we rescaled all data to $100 \%$ between the sizes of 64 and $0.63 \mu \mathrm{m}$. The reader should be aware of this exercise when comparing the data presented in Tables 4, 5, and 6, all on CD-ROM only (back pocket, this volume) and should note that the data presented in Tables 4 and 5 were generated using SediGraph instruments, whereas those in Table 6 were obtained by using a Coulter Counter.

In general, there is good agreement between data sets generated by each piece of analytical equipment. There remains a slight difference between SediGraph plots and the other data. This is most apparent in the range between 6 and $11 \phi$, where the values produced by the SediGraph are generally lower than those generated by the other

Table 1. Cumulative data for interlaboratory comparison between SediGraph sizing machines operated at Cardiff and Memorial.

\begin{tabular}{|c|c|c|c|c|c|c|c|c|c|c|c|c|c|}
\hline \multirow[b]{2}{*}{$\begin{array}{l}\text { Diameter } \\
(\mu \mathrm{m})\end{array}$} & \multirow[b]{2}{*}{$\phi$} & \multicolumn{4}{|c|}{$\begin{array}{l}\text { 155-939B-6H-3, 52-54 cm } \\
\text { (Fig. 1A) }\end{array}$} & \multicolumn{4}{|c|}{$\begin{array}{l}\text { 155-940A-4H-5, 127-130 cm } \\
\text { (Fig. 1B) }\end{array}$} & \multicolumn{4}{|c|}{$\begin{array}{l}\text { 155-946A-1H-2, 23-25 cm } \\
\text { (Fig. 1C) }\end{array}$} \\
\hline & & Cardiff & $\begin{array}{c}\text { Cum } \\
(\%)\end{array}$ & Memorial & $\begin{array}{c}\text { Cum } \\
(\%)\end{array}$ & Cardiff & $\begin{array}{c}\text { Cum } \\
(\%)\end{array}$ & Memorial & $\begin{array}{c}\text { Cum } \\
(\%)\end{array}$ & Cardiff & $\begin{array}{c}\text { Cum } \\
(\%)\end{array}$ & Memorial & $\begin{array}{l}\text { Cum } \\
(\%)\end{array}$ \\
\hline 44.00 & 4.5 & 1.3 & 1.3 & 2.5 & 2.5 & 0.9 & 0.9 & 1.1 & 1.1 & 0.7 & 0.7 & 2.7 & 2.7 \\
\hline 31.00 & 5.0 & 8.1 & 9.4 & 5.6 & 8.1 & 2.1 & 3.0 & 0.7 & 1.8 & 10.6 & 11.3 & 8.3 & 11.0 \\
\hline 22.10 & 5.5 & 12.6 & 22.0 & 7.4 & 15.5 & 6.4 & 9.4 & 4.2 & 6.0 & 23.0 & 34.3 & 18.4 & 29.4 \\
\hline 15.60 & 6.0 & 11.4 & 33.4 & 6.5 & 22.0 & 11.4 & 20.8 & 9.1 & 15.1 & 24.8 & 59.1 & 21.1 & 50.5 \\
\hline 11.00 & 6.5 & 9.1 & 42.9 & 6.6 & 28.6 & 11.4 & 32.2 & 9.9 & 25.0 & 16.1 & 75.2 & 13.0 & 63.5 \\
\hline 7.80 & 7.0 & 8.1 & 51.0 & 6.5 & 35.1 & 9.6 & 41.8 & 9.0 & 34.0 & 7.9 & 83.1 & 6.5 & 70.0 \\
\hline 5.50 & 7.5 & 7.7 & 58.7 & 6.5 & 41.6 & 9.2 & 51.0 & 7.8 & 41.8 & 4.6 & 87.7 & 4.1 & 74.1 \\
\hline 3.90 & 8.0 & 6.1 & 64.8 & 6.3 & 47.9 & 6.4 & 57.4 & 6.7 & 48.5 & 3.1 & 90.8 & 2.6 & 76.7 \\
\hline 2.83 & 8.5 & 4.6 & 69.4 & 5.3 & 53.2 & 5.7 & 63.1 & 5.2 & 53.7 & 1.7 & 92.5 & 2.3 & 79.0 \\
\hline 2.00 & 9.0 & 3.7 & 73.1 & 5.4 & 58.6 & 5.4 & 68.5 & 5.1 & 58.8 & 1.4 & 93.9 & 2.2 & 81.2 \\
\hline 1.39 & 9.5 & 3.6 & 76.7 & 4.3 & 62.9 & 4.4 & 72.9 & 4.2 & 63.0 & 1.7 & 95.6 & 2.1 & 83.3 \\
\hline 0.98 & 10.0 & 2.6 & 79.3 & 4.3 & 67.2 & 3.0 & 75.9 & 3.4 & 66.4 & 1.0 & 96.6 & 2.0 & 85.3 \\
\hline 0.69 & 10.5 & 2.6 & 81.9 & 4.6 & 71.8 & 3.7 & 79.6 & 3.6 & 70.0 & 0.4 & 97.0 & 1.6 & 86.9 \\
\hline 0.50 & 11.0 & 3.2 & 85.1 & 3.9 & 75.7 & 2.6 & 82.2 & 2.3 & 72.3 & 0.7 & 97.7 & 1.9 & 88.8 \\
\hline 0.49 & 11.5 & 14.9 & 100.0 & 24.3 & 100.0 & 17.8 & 100.0 & 27.7 & 100.0 & 2.3 & 100.0 & 11.2 & 100.0 \\
\hline
\end{tabular}

Note: $\operatorname{Cum}(\%)=$ cumulative percentage 
Table 2. Mediam and mode $(\mu \mathrm{m})$ data of interlaboratory analyses carried out on SediGraph sizing machines operated at Cardiff and Memorial.

\begin{tabular}{lllllrr}
\hline \multirow{2}{*}{$\begin{array}{c}\text { Hole, core, section, } \\
\text { interval }(\mathrm{cm})\end{array}$} & \multicolumn{2}{c}{ Median $(\mu \mathrm{m})$} & & \multicolumn{2}{c}{ Mode $(\mu \mathrm{m})$} \\
\cline { 2 - 3 } \cline { 6 - 6 } & Cardiff & Memorial & & Cardiff & Memorial \\
\hline 939B-6H-3, 52-54 & 25.14 & 26.31 & & 8.16 & 3.45 \\
940A-4H-5, 127-130 & 16.28 & 14.89 & & 5.77 & 3.60 \\
946A-1H-2, 23-25 & 17.93 & 22.10 & & 22.10 & 15.73 \\
\hline
\end{tabular}

sizing instruments. Similar findings were also reported by Singer et al. (1988)

Figures 4, 5, and 6 provide correlation data between the SediGraph, the Coulter Counter, and the Coulter Laser for Samples 155930D-6H-5, 62-65 cm (Part I; Fig. 4), 155-930D-6H-5, 62-65 cm (Part II; Fig. 5), and 155-931B-12X-3, 108-110 cm (Fig. 6), respectively. There are variable levels of correlation between the data. The range of correlation extends from a low 0.4 (Fig. 5B) to a high 0.993 (Fig. 6B). It is interesting to note that both of these values were obtained for the correlation between the Sedigraph and the Laser, whereas the poor correlation resulted from the fine-grained fractions as determined by the SediGraph. Averaging all three samples for each correlation, the highest degree of correlation occurs between the Coulter Counter and the Coulter Laser-sizer (0.806); average correlations of 0.787 and 0.722 exist between the SediGraph and the Coulter Counter, and the SediGraph and the Coulter Laser-sizer, respectively.

The lower correlations are attributed to the fact that the Coulter Counter and Coulter Laser equipment usually measure a different spectrum of size compared with the SediGraph. Syvitski et al. (1991) reported that the SediGraph was prone to providing data that were too fine, illustrating the point with an admixture of a bimodal standard. They also noted that poor results from one or more instruments may not necessarily reflect the analytical technique of that instrument; rather, it may result from local analytical error or machine difficulty.

Because this contribution is a data report, the reader is referred to Syvitski et al. (1991) for a comprehensive review and explanation of sizing techniques and data comparisons.

\section{ACKNOWLEDGMENTS}

The authors would like to express their thanks to the ODP reviewers for constructive thoughts and editorial efforts. Dr. Adrian Cramp thanks Gerard O'Sullivan for handling the initial translation of phi and micron data from all laboratories, and NERC (UK) for their continuing support of the Ocean Drilling Program, and the participation of individuals therein.

\section{REFERENCES}

Agrawal, Y.C., McCave, I.N., and Riley, J.B., 1991. Laser diffraction size analysis. In Syvitski, J.P.M. (Ed.), Principles, Methods, and Application of Particle Size Analysis: (Cambridge Univ. Press), 119-128.

Coakley, J.P., and Syvitski, J.P.M., 1991. SediGraph technique. In Syvitski, J.P.M. (Ed.), Principles, Methods and Application of Particle Size Analysis: New York (Cambridge Univ. Press), 129-142.

Flood, R.D., Piper, D.J.W., Klaus, A., et al., 1995. Proc. ODP, Init. Repts., 155: College Station, TX (Ocean Drilling Program).

Hendrix, W.P., and Orr, C., 1972. Automatic sedimentation size analysis instrument. In Groves, M.J., and Wyatt-Sargent, J.L (Eds.), Particle Size Analysis 1970. London Soc. Analyt. Chem., 133-146.

Manley, P.L., and Flood, R.D., 1988. Cyclic sediment deposition within Amazon deep-sea fan. AAPG Bull., 72:912-925.

McCave, I.N., Bryant, R.J., Cook, H.F., and Coughanowr, C.A., 1986. Evaluation of a laser-diffraction-size analyzer for use with natural sediments. $J$. Sediment. Petrol., 56:561-564.

Milligan, T.G., and Kranck, K., 1991. Electroresistance particle size analysers. In Syvitski, J.P.M. (Ed.), Principles, Methods and Application of Particle Size Analysis: New York (Cambridge Univ. Press), 109-117.

Singer, J.K., Anderson, J.B., Ledbetter, M.T., McCave, I.N., Jones, K.P.N., and Wright, R., 1988. An assessment of analytical techniques for the size analysis of fine-grained sediments. J. Sediment. Petrol., 58:534-543.

Stein, R., 1985. Rapid grain size analyses of clay and silt fraction by Sedigraph 5000D: comparison with Coulter Counter and Atterberg methods. J. Sediment. Petrol., 55:590-615.

Syvitski, J.P.M., 1991. Principles, Methods and Application of Particle Size Analysis: New York (Cambridge Univ. Press).

Syvitski, J.P.M., LeBlanc, K.W.G., and Asprey, K.W., 1991. Interlaboratory interinstrumentation calibration experiment. In Syvitski, J.P.M. (Ed.), Principles, Methods and Application of Particle Size Analysis: New York (Cambridge Univ. Press), 174-193.

Date of initial receipt: 5 December 1995

Date of acceptance: 18 April 1996 Ms 155SR-242 
A
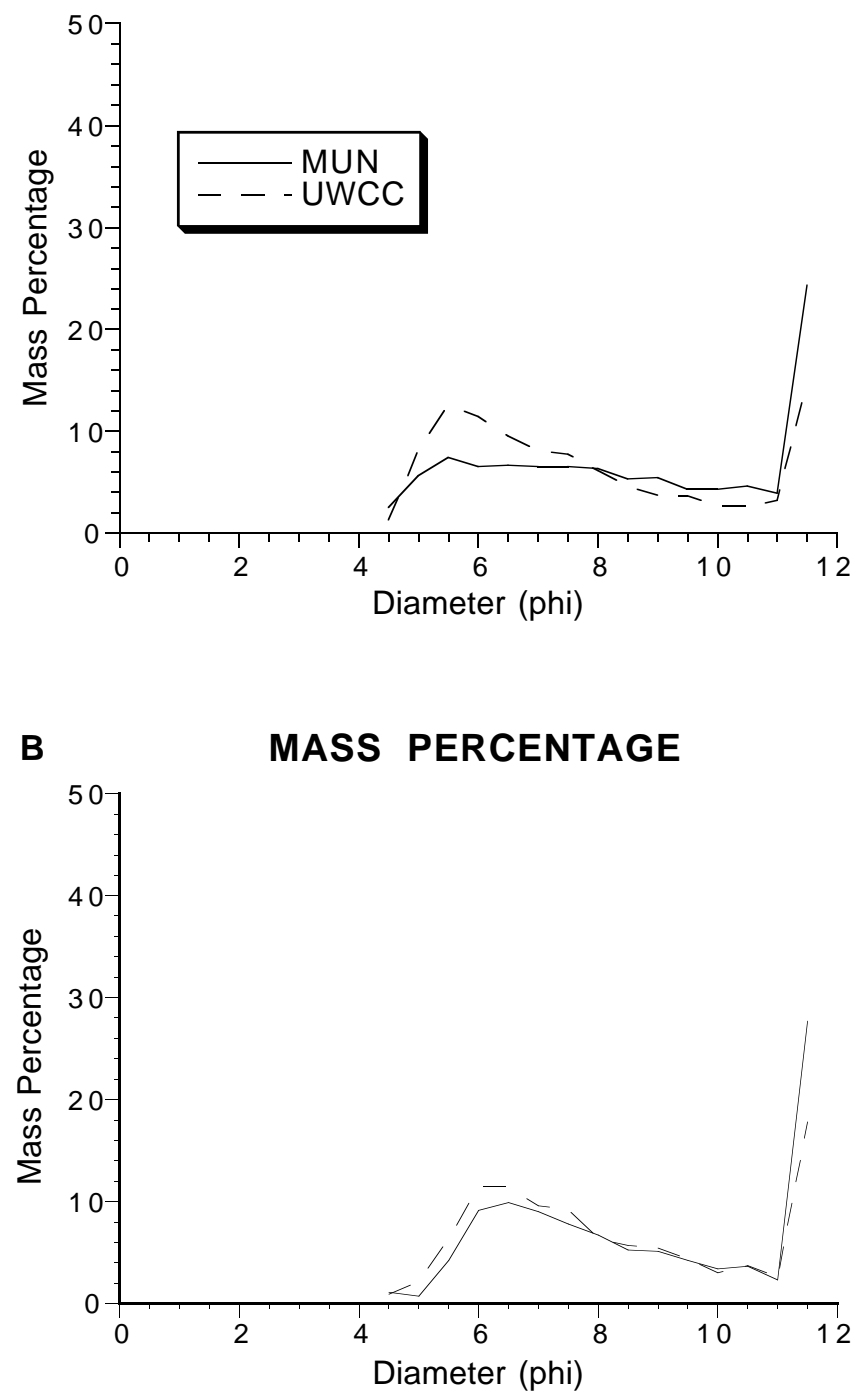

C

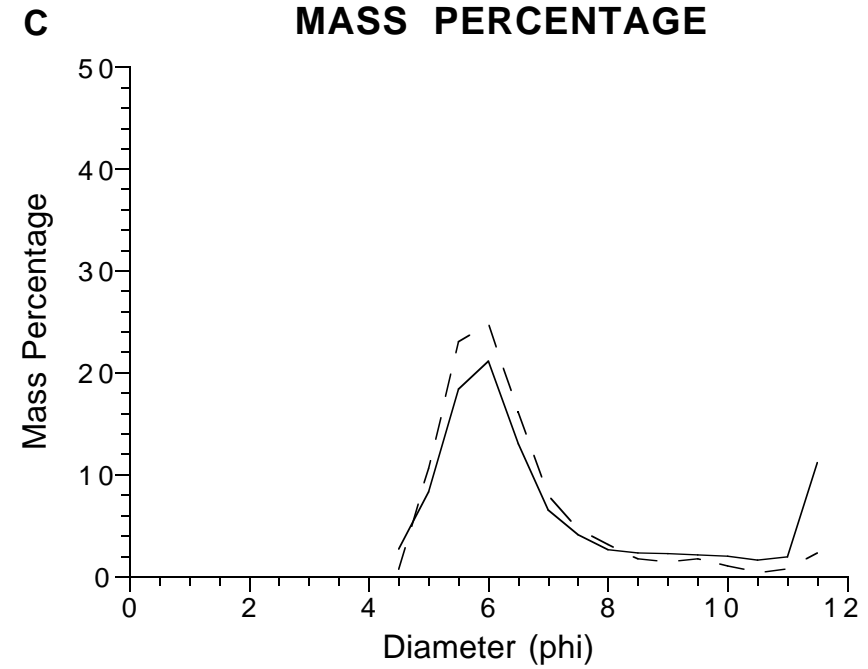

CUMULATIVE FREQUENCY

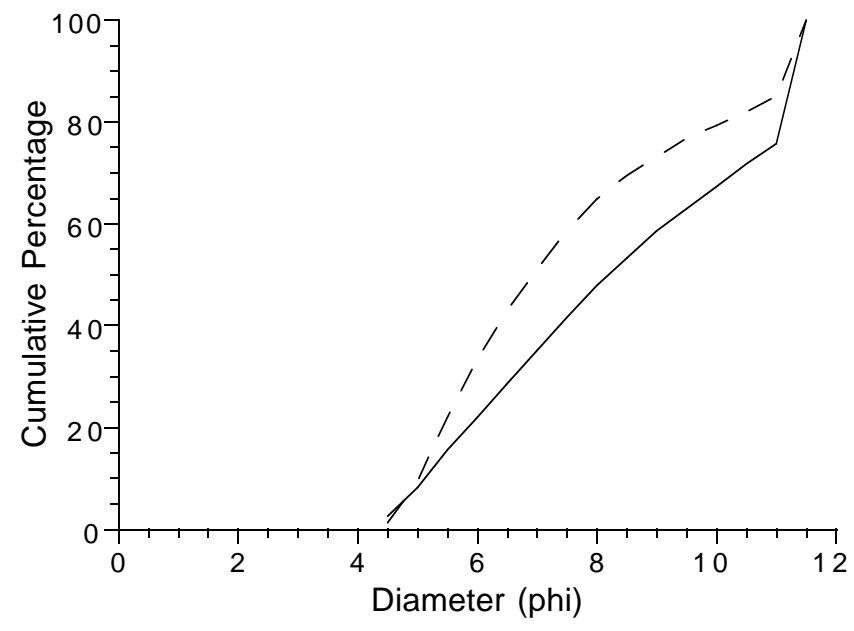

CUMULATIVE FREQUENCY

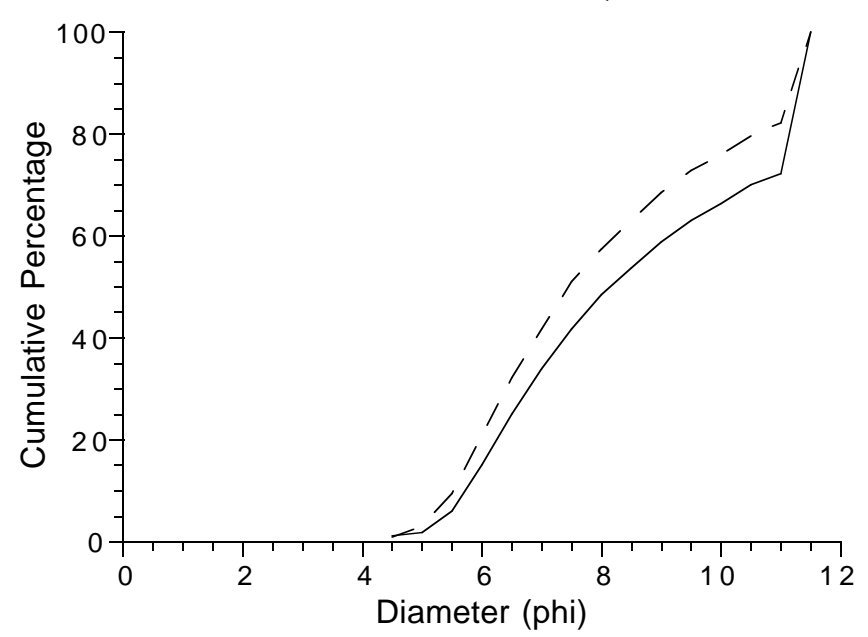

CUMULATIVE FREQUENCY

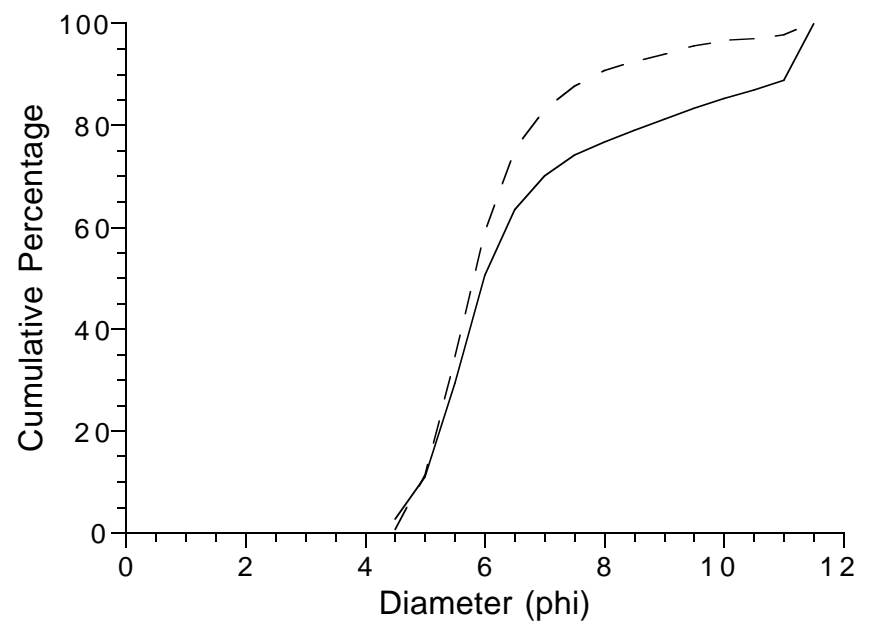

Figure 1. Comparison of grain-size data generated from Micromeritics SediGraph machines operated at Cardiff (UWCC) and St. Johns, Memorial (MUN). A. Sample 155-939B-6H-3, 52-54 cm. B. Sample 155-940A-4H-5, 127-130 cm. C. Sample 155-946-1H-2, $23-25 \mathrm{~cm}$. 

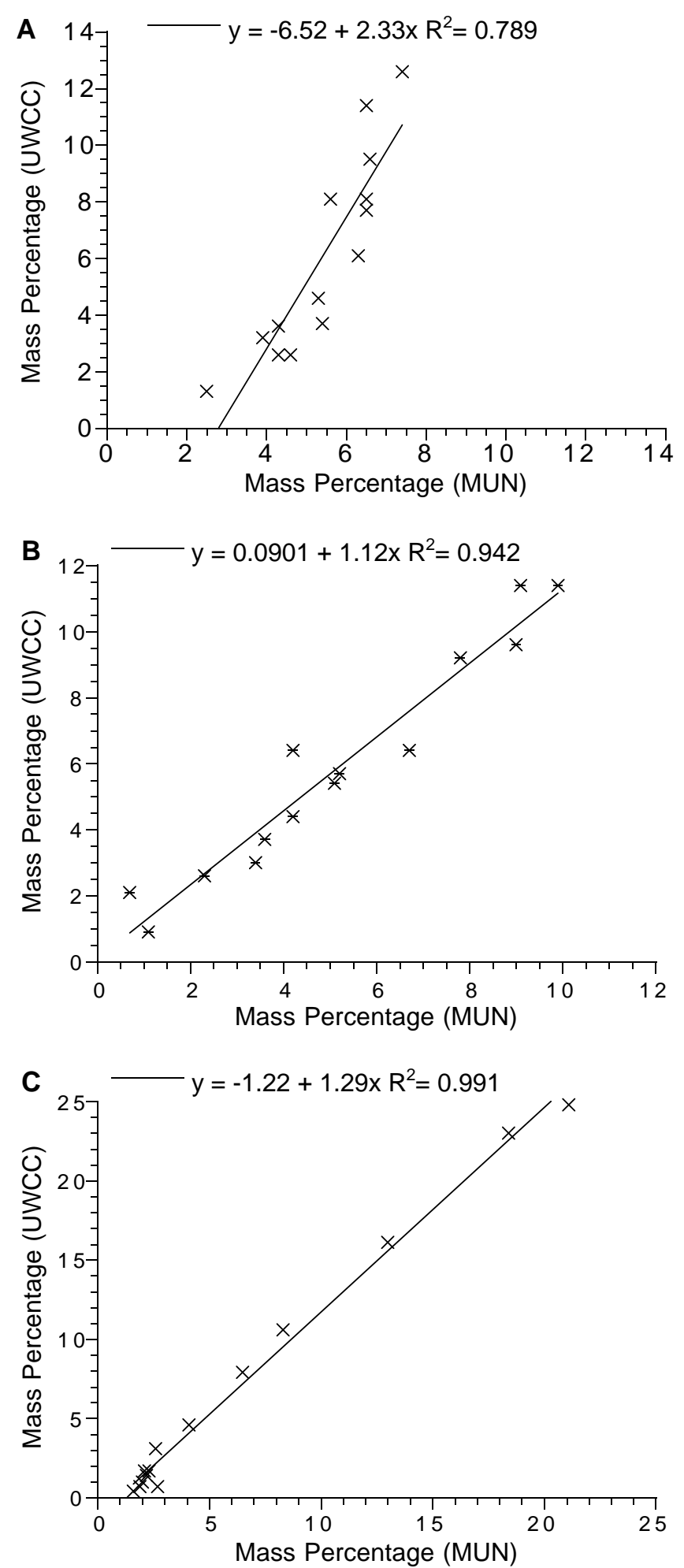

Figure 2. Correlation between Micromeritics SediGraph machines operated at Cardiff and Memorial. A. Sample 155-939B-6H-3, 52-54 cm. B. Sample 155940A-4H-5, 127-130 cm. C. Sample 155-946-1H-2, 23-25 cm. 
Table 3. Interlaboratory comparison of sizing equipment: cumulative data for Coulter Counter (BIO), Micromeritics SediGraph, and Coulter Laser.

\begin{tabular}{|c|c|c|c|c|c|c|c|c|c|c|c|}
\hline \multirow{2}{*}{$\begin{array}{l}\text { Diameter } \\
(\mu \mathrm{m})\end{array}$} & \multirow[b]{2}{*}{$\phi$} & \multicolumn{10}{|c|}{$\begin{array}{c}\text { 155-930D-6H-5, 62-65 cm (Part I) } \\
\text { (Fig. 3A) }\end{array}$} \\
\hline & & \multicolumn{2}{|c|}{$\mathrm{CC} \mathrm{A}$} & \multicolumn{2}{|c|}{$\mathrm{CC} \mathrm{B}$} & \multicolumn{2}{|c|}{ Sedigraph A } & \multicolumn{2}{|c|}{ Sedigraph B } & \multicolumn{2}{|c|}{ Laser } \\
\hline 64 & 3.97 & 0.9 & 0.9 & 0.2 & 0.2 & & & & & 0.7 & 0.7 \\
\hline 51 & 4.3 & 1.2 & 2.1 & 0.4 & 0.6 & 2.3 & 2.3 & 0.2 & 0.2 & & \\
\hline 45 & 4.47 & & & & & & & & & 1.6 & 2.3 \\
\hline 40 & 4.63 & 1.2 & 3.3 & 1.1 & 1.7 & 0.0 & 2.3 & 1.5 & 1.7 & & \\
\hline 32 & 4.97 & 0.9 & 4.2 & 1.0 & 2.7 & 0.4 & 2.7 & 0.6 & 2.3 & 3.4 & 5.7 \\
\hline 25 & 5.3 & 1.3 & 5.5 & 1.3 & 4.0 & 0.4 & 3.1 & 1.2 & 3.5 & & \\
\hline 22.5 & 5.47 & & & & & & & & & 6.9 & 12.6 \\
\hline 20 & 5.63 & 2.8 & 8.3 & 1.9 & 5.9 & 2.0 & 5.1 & 2.9 & 6.4 & & \\
\hline 16 & 5.97 & 5.6 & 13.9 & 4.1 & 10.0 & 3.7 & 8.8 & 4.4 & 10.8 & 9.2 & 21.8 \\
\hline 13 & 6.3 & 7.6 & 21.5 & 6.5 & 16.5 & 4.4 & 13.2 & 4.4 & 15.2 & & \\
\hline 11.2 & 6.47 & & & & & & & & & 11.6 & 33.4 \\
\hline 10 & 6.63 & 9.3 & 30.8 & 8.0 & 24.5 & 8.0 & 21.2 & 7.4 & 22.6 & & \\
\hline 8 & 6.97 & 9.5 & 40.3 & 9.0 & 33.5 & 8.7 & 29.9 & 8.0 & 30.6 & 11.8 & 45.1 \\
\hline 6.4 & 7.3 & 9.6 & 49.9 & 9.3 & 42.8 & 8.7 & 38.6 & 8.1 & 38.7 & & \\
\hline 5.6 & 7.47 & & & & & & & & & 11.8 & 57.0 \\
\hline 5 & 7.63 & 8.3 & 58.2 & 8.4 & 51.2 & 9.4 & 48.0 & 10.0 & 48.7 & & \\
\hline 4 & 7.97 & 7.3 & 65.5 & 7.4 & 58.6 & 9.1 & 57.1 & 8.6 & 57.3 & 10.5 & 67.5 \\
\hline 3.2 & 8.3 & 6.0 & 71.5 & 7.6 & 66.2 & 7.8 & 64.9 & 7.1 & 64.4 & & \\
\hline 2.8 & 8.47 & & & & & & & & & 10.0 & 77.4 \\
\hline 2.5 & 8.63 & 5.5 & 77.0 & 7.3 & 73.5 & 6.5 & 71.4 & 7.2 & 71.6 & & \\
\hline 2 & 8.97 & 4.7 & 81.7 & 5.9 & 79.4 & 5.7 & 77.1 & 6.2 & 77.8 & 8.1 & 85.6 \\
\hline 1.6 & 9.3 & 4.0 & 85.7 & 4.9 & 84.3 & 5.6 & 82.7 & 4.5 & 82.3 & & \\
\hline 1.4 & 9.47 & & & & & & & & & 7.7 & 93.3 \\
\hline 1.3 & 9.63 & 3.8 & 89.5 & 4.9 & 89.2 & 4.9 & 87.6 & 4.4 & 86.7 & & \\
\hline 1 & 9.97 & 3.7 & 93.2 & 5.3 & 94.5 & 5.4 & 93.0 & 5.4 & 92.1 & 6.7 & 100.0 \\
\hline 0.79 & 10.31 & 3.9 & 97.1 & 3.5 & 98.0 & 4.0 & 97.0 & 4.4 & 96.5 & & \\
\hline 0.63 & 10.63 & 2.9 & 100.0 & 2.0 & 100.0 & 3.0 & 100.0 & 3.5 & 100.0 & & \\
\hline
\end{tabular}

Notes: CC= Coulter Counter. CC A and CC B together with SediGraph A and B are replicate sample runs.

Table 3 (continued).

\begin{tabular}{|c|c|c|c|c|c|c|c|c|c|c|c|}
\hline \multirow{2}{*}{$\begin{array}{l}\text { Diameter } \\
(\mu \mathrm{m})\end{array}$} & \multirow[b]{2}{*}{$\phi$} & \multicolumn{10}{|c|}{$\begin{array}{c}\text { 155-930D-6H-5, 62-65 cm (Part II) } \\
\text { (Fig. 3B) }\end{array}$} \\
\hline & & \multicolumn{2}{|c|}{$\mathrm{CC} \mathrm{A}$} & \multicolumn{2}{|c|}{$\mathrm{CC} \mathrm{B}$} & \multicolumn{2}{|c|}{ Sedigraph A } & \multicolumn{2}{|c|}{ Sedigraph B } & \multicolumn{2}{|c|}{ Laser } \\
\hline 64 & 3.97 & 0.2 & 0.2 & 0.2 & 0.2 & & & & & 0.6 & 0.6 \\
\hline 51 & 4.3 & 1.1 & 1.3 & 0.7 & 0.9 & 1.2 & 1.2 & 0.9 & 0.9 & & \\
\hline 45 & 4.47 & & & & & & & & & 0.4 & 1.0 \\
\hline 40 & 4.63 & 0.5 & 1.8 & 0.4 & 1.3 & 0.3 & 1.5 & 1.1 & 2.0 & & \\
\hline 32 & 4.97 & 0.3 & 2.1 & 0.6 & 2.0 & 0.6 & 2.1 & 0.8 & 2.7 & 2.6 & 3.6 \\
\hline 25 & 5.3 & 1.1 & 3.2 & 1.0 & 2.9 & 0.6 & 2.8 & 1.2 & 3.9 & & \\
\hline 22.5 & 5.47 & & & & & & & & & 3.6 & 7.2 \\
\hline 20 & 5.63 & 2.0 & 5.2 & 1.9 & 4.8 & 2.5 & 5.2 & 2.4 & 6.3 & & \\
\hline 16 & 5.97 & 4.0 & 9.1 & 5.3 & 10.1 & 4.0 & 9.2 & 4.2 & 10.6 & 7.3 & 14.5 \\
\hline 13 & 6.3 & 6.1 & 15.3 & 7.4 & 17.6 & 5.4 & 14.5 & 5.0 & 15.5 & & \\
\hline 11.2 & 6.47 & & & & & & & & & 9.8 & 24.3 \\
\hline 10 & 6.63 & 8.0 & 23.3 & 8.6 & 26.1 & 8.0 & 22.5 & 6.9 & 22.5 & & \\
\hline 8 & 6.97 & 8.8 & 32.1 & 9.2 & 35.4 & 7.0 & 29.5 & 7.7 & 30.2 & 24.1 & 48.4 \\
\hline 6.4 & 7.3 & 9.3 & 41.3 & 9.3 & 44.7 & 8.0 & 37.5 & 7.7 & 37.9 & & \\
\hline 5.6 & 7.47 & & & & & & & & & 11.7 & 60.1 \\
\hline 5 & 7.63 & 8.3 & 49.6 & 8.2 & 52.9 & 9.5 & 47.0 & 8.3 & 46.2 & & \\
\hline 4 & 7.97 & 7.4 & 57.0 & 7.1 & 60.0 & 6.7 & 53.7 & 7.1 & 53.2 & 10.2 & 70.3 \\
\hline 3.2 & 8.3 & 8.3 & 65.3 & 7.5 & 67.5 & 6.3 & 59.9 & 7.2 & 60.5 & & \\
\hline 2.8 & 8.47 & & & & & & & & & 9.5 & 79.8 \\
\hline 2.5 & 8.63 & 6.3 & 71.6 & 6.7 & 74.2 & 6.4 & 66.4 & 6.3 & 66.8 & & \\
\hline 2 & 8.97 & 6.0 & 77.5 & 5.8 & 80.0 & 6.4 & 72.8 & 5.9 & 72.7 & 7.5 & 87.3 \\
\hline 1.6 & 9.3 & 5.4 & 82.9 & 4.6 & 84.6 & 6.1 & 78.9 & 6.2 & 78.9 & & \\
\hline 1.4 & 9.47 & & & & & & & & & 6.9 & 94.2 \\
\hline 1.3 & 9.63 & 5.2 & 88.1 & 4.7 & 89.2 & 4.7 & 83.6 & 4.8 & 83.7 & & \\
\hline 1 & 9.97 & 5.6 & 93.7 & 4.6 & 93.8 & 5.7 & 89.3 & 5.4 & 89.1 & 5.8 & 100.0 \\
\hline 0.79 & 10.31 & 3.7 & 97.4 & 3.9 & 97.7 & 5.1 & 94.3 & 5.3 & 94.4 & & \\
\hline 0.63 & 10.63 & 2.6 & 100.0 & 2.3 & 100.0 & 5.7 & 100.0 & 5.6 & 100.0 & & \\
\hline
\end{tabular}


Table 3 (continued).

\begin{tabular}{|c|c|c|c|c|c|c|c|c|c|c|c|}
\hline \multirow{2}{*}{$\begin{array}{l}\text { Diameter } \\
(\mu \mathrm{m})\end{array}$} & \multirow[b]{2}{*}{$\phi$} & \multicolumn{10}{|c|}{$\begin{array}{l}\text { 155-931B-12X-3, 108-110 cm } \\
\text { (Fig. 3C) }\end{array}$} \\
\hline & & \multicolumn{2}{|c|}{$\mathrm{CC} \mathrm{A}$} & \multicolumn{2}{|c|}{$\mathrm{CC} \mathrm{B}$} & \multicolumn{2}{|c|}{ Sedigraph A } & \multicolumn{2}{|c|}{ Sedigraph B } & \multicolumn{2}{|c|}{ Laser } \\
\hline 64 & 3.97 & 0.2 & 0.2 & 0.2 & 0.2 & & & & & 1.3 & 1.3 \\
\hline 51 & 4.3 & 0.2 & 0.5 & 0.2 & 0.5 & 0.3 & 0.3 & 1.3 & 1.3 & & \\
\hline 45 & 4.47 & & & & & & & & & 3.0 & 4.3 \\
\hline 40 & 4.63 & 0.6 & 1.1 & 0.7 & 1.1 & 2.2 & 2.5 & 0.4 & 1.8 & & \\
\hline 32 & 4.97 & 1.2 & 2.3 & 0.6 & 1.8 & 1.5 & 4.0 & 0.9 & 2.6 & 5.9 & 10.2 \\
\hline 25 & 5.3 & 2.2 & 4.4 & 2.0 & 3.7 & 5.3 & 9.2 & 3.7 & 6.3 & & \\
\hline 22.5 & 5.47 & & & & & & & & & 9.6 & 19.8 \\
\hline 20 & 5.63 & 5.6 & 10.0 & 4.1 & 7.8 & 7.5 & 16.7 & 6.6 & 12.9 & & \\
\hline 16 & 5.97 & 7.5 & 17.5 & 7.1 & 14.9 & 8.5 & 25.2 & 7.1 & 20.0 & 10.7 & 30.5 \\
\hline 13 & 6.3 & 9.6 & 27.1 & 9.3 & 24.2 & 8.2 & 33.4 & 7.2 & 27.2 & & \\
\hline 11.2 & 6.47 & & & & & & & & & 11.0 & 41.4 \\
\hline 10 & 6.63 & 9.6 & 36.7 & 10.1 & 34.3 & 10.4 & 43.8 & 9.7 & 36.9 & & \\
\hline 8 & 6.97 & 8.8 & 45.5 & 9.3 & 43.6 & 7.6 & 51.5 & 8.1 & 45.0 & 9.7 & 51.1 \\
\hline 6.4 & 7.3 & 7.8 & 53.3 & 8.3 & 51.9 & 7.3 & 58.8 & 7.5 & 52.5 & & \\
\hline 5.6 & 7.47 & & & & & & & & & 9.4 & 60.5 \\
\hline 5 & 7.63 & 6.3 & 59.6 & 6.8 & 58.7 & 9.1 & 67.9 & 7.9 & 60.5 & & \\
\hline 4 & 7.97 & 5.3 & 64.8 & 5.7 & 64.4 & 6.0 & 73.9 & 6.0 & 66.5 & 8.7 & 69.2 \\
\hline 3.2 & 8.3 & 6.0 & 70.8 & 6.5 & 70.8 & 4.4 & 78.3 & 5.0 & 71.5 & & \\
\hline 2.8 & 8.47 & & & & & & & & & 9.0 & 78.2 \\
\hline 2.5 & 8.63 & 5.6 & 76.4 & 5.3 & 76.2 & 4.1 & 82.4 & 5.0 & 76.5 & & \\
\hline 2 & 8.97 & 4.8 & 81.2 & 4.7 & 80.9 & 4.7 & 87.1 & 4.4 & 80.9 & 8.0 & 86.2 \\
\hline 1.6 & 9.3 & 4.2 & 85.4 & 4.2 & 85.0 & 5.4 & 92.5 & 4.1 & 85.0 & & \\
\hline 1.4 & 9.47 & & & & & & & & & 7.6 & 93.8 \\
\hline 1.3 & 9.63 & 4.2 & 89.5 & 4.2 & 89.2 & 3.1 & 95.6 & 3.5 & 88.5 & & \\
\hline 1 & 9.97 & 4.1 & 93.6 & 4.1 & 93.3 & 2.1 & 97.7 & 4.4 & 93.0 & 6.2 & 100.0 \\
\hline 0.79 & 10.31 & 3.7 & 97.3 & 3.8 & 97.2 & 2.2 & 99.9 & 3.8 & 96.8 & & \\
\hline 0.63 & 10.63 & 2.7 & 100.0 & 2.9 & 100.0 & 0.2 & 100.0 & 3.2 & 100.0 & & \\
\hline
\end{tabular}

Figure 3. Comparative cumulative percentages with the Coulter Counter (CC), Micromeritics SediGraph, and the Coulter Laser system. A. Sample 155-930D-6H-5, 62-65 cm. B. Sample 155-930D-6H-5, 62-65 cm. C. Sample 155-931B-12X-3, 108-110 cm.

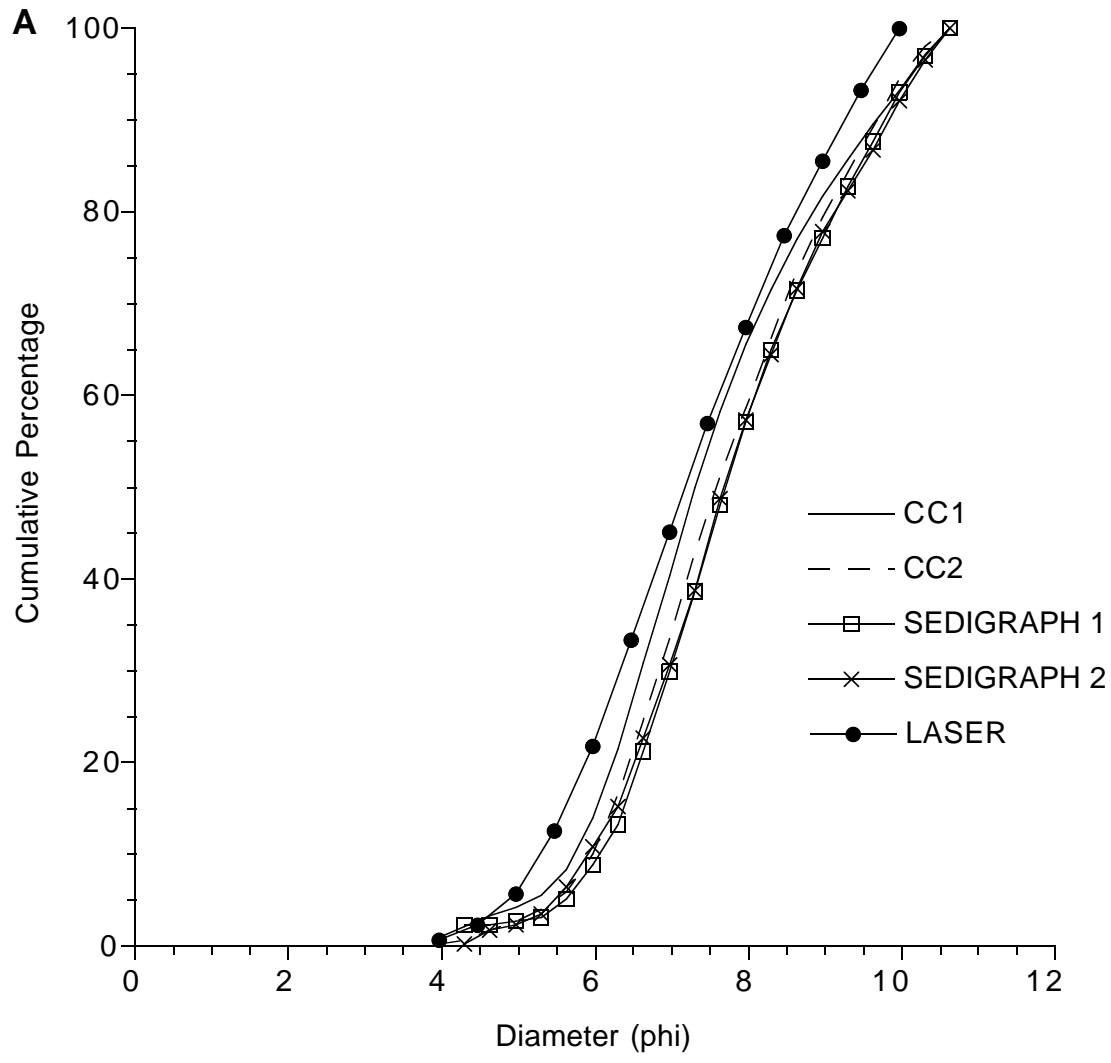



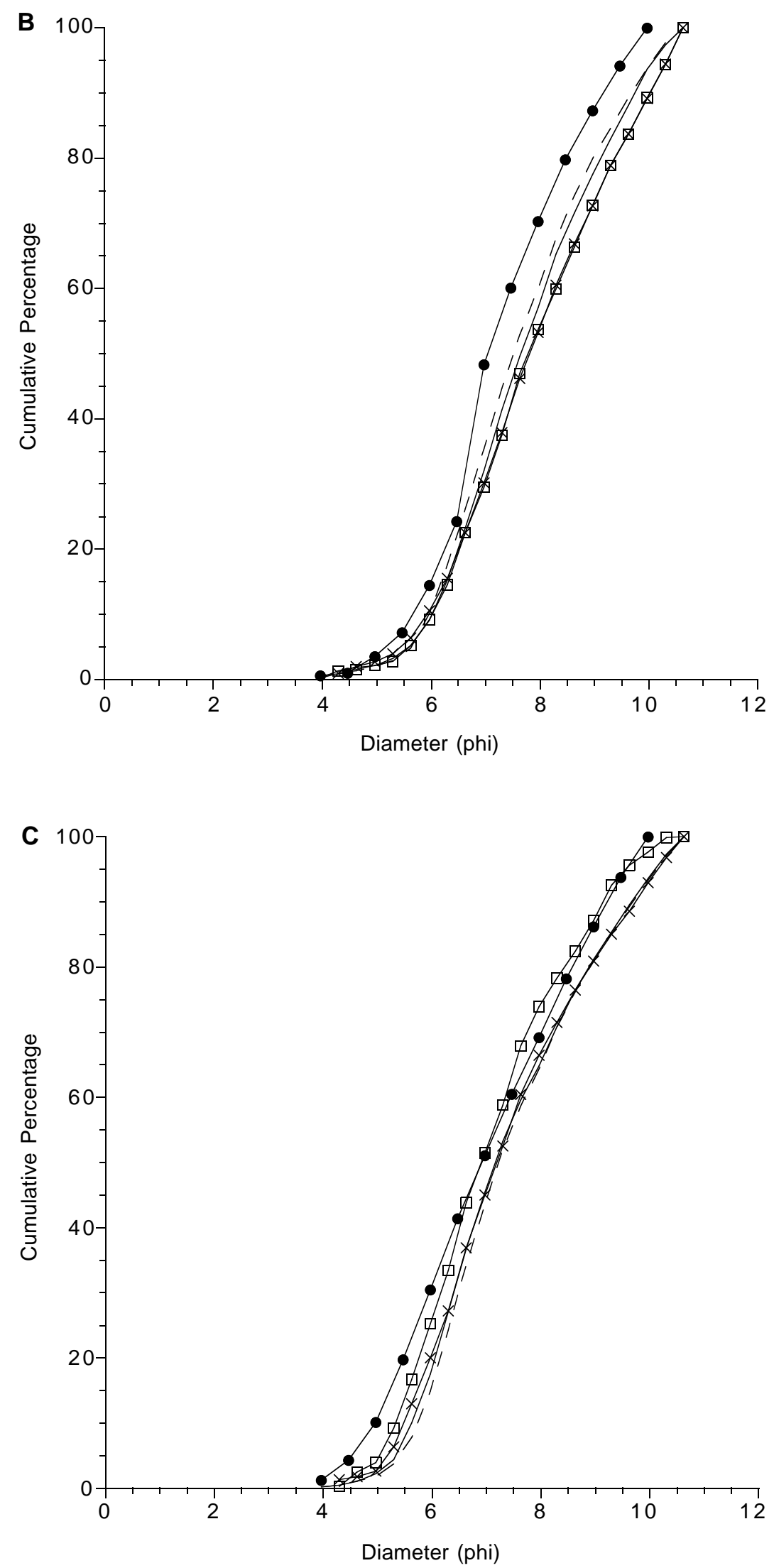

Figure 3 (continued). 

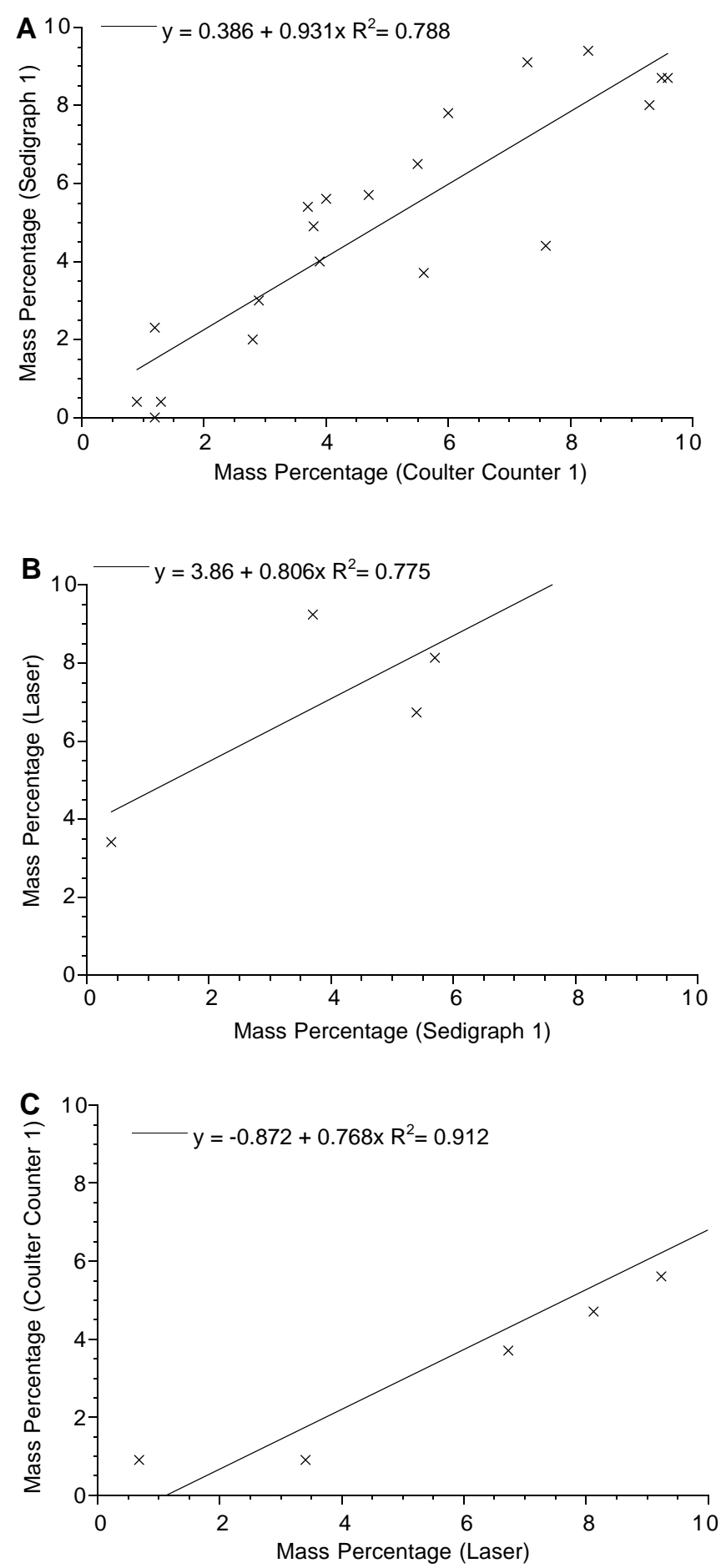

Figure 4. Correlation between the (A) SediGraph and Coulter Counter, (B) Laser and SediGraph, (C) and Coulter Counter and Laser for Sample 155-930D-6H$5,62-65 \mathrm{~cm}$ (Part I). 

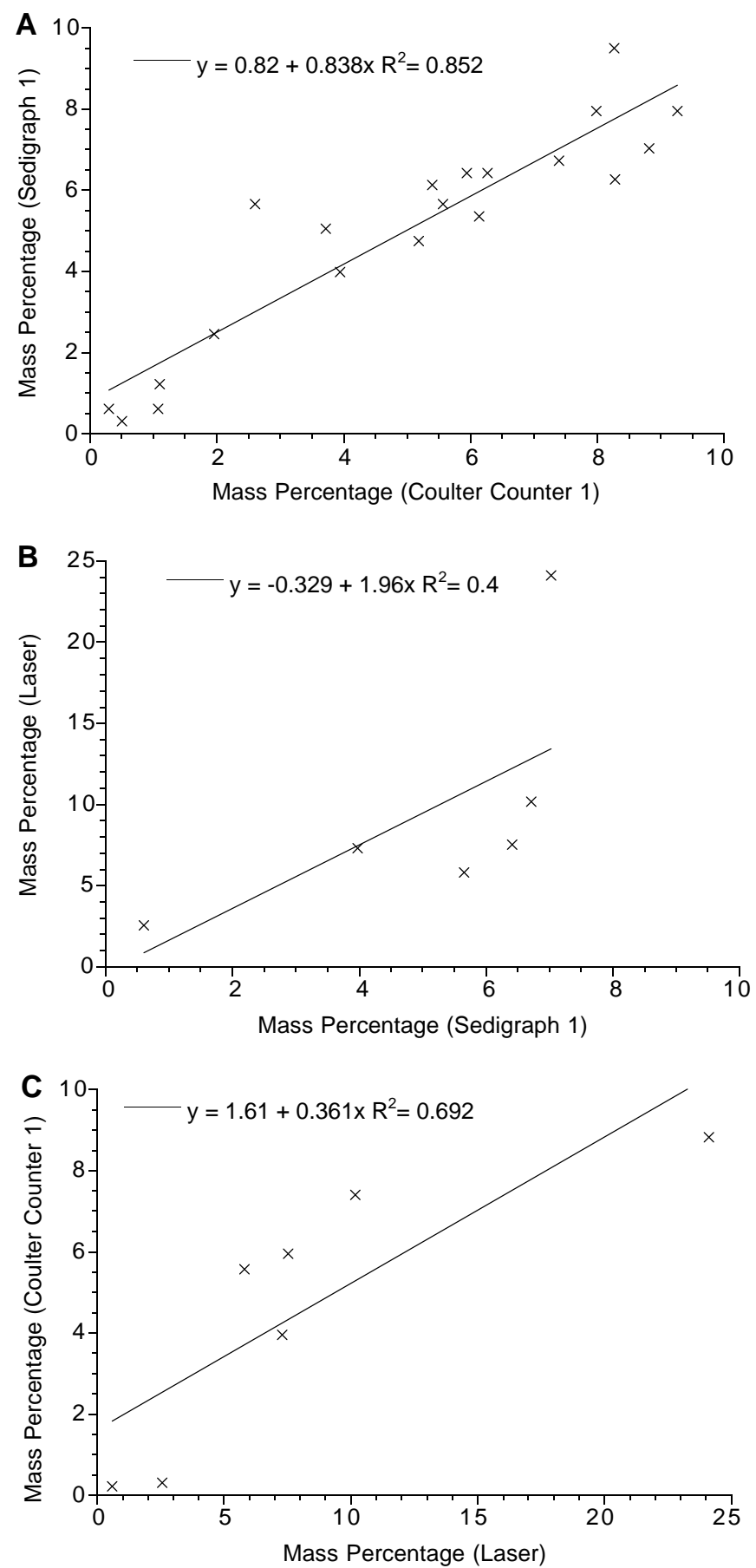

Figure 5. Correlation between the (A) SediGraph and Coulter Counter, (B) Laser and SediGraph, (C) and Coulter Counter and Laser for Sample 155-930D-6H$5,62-65 \mathrm{~cm}($ Part II). 

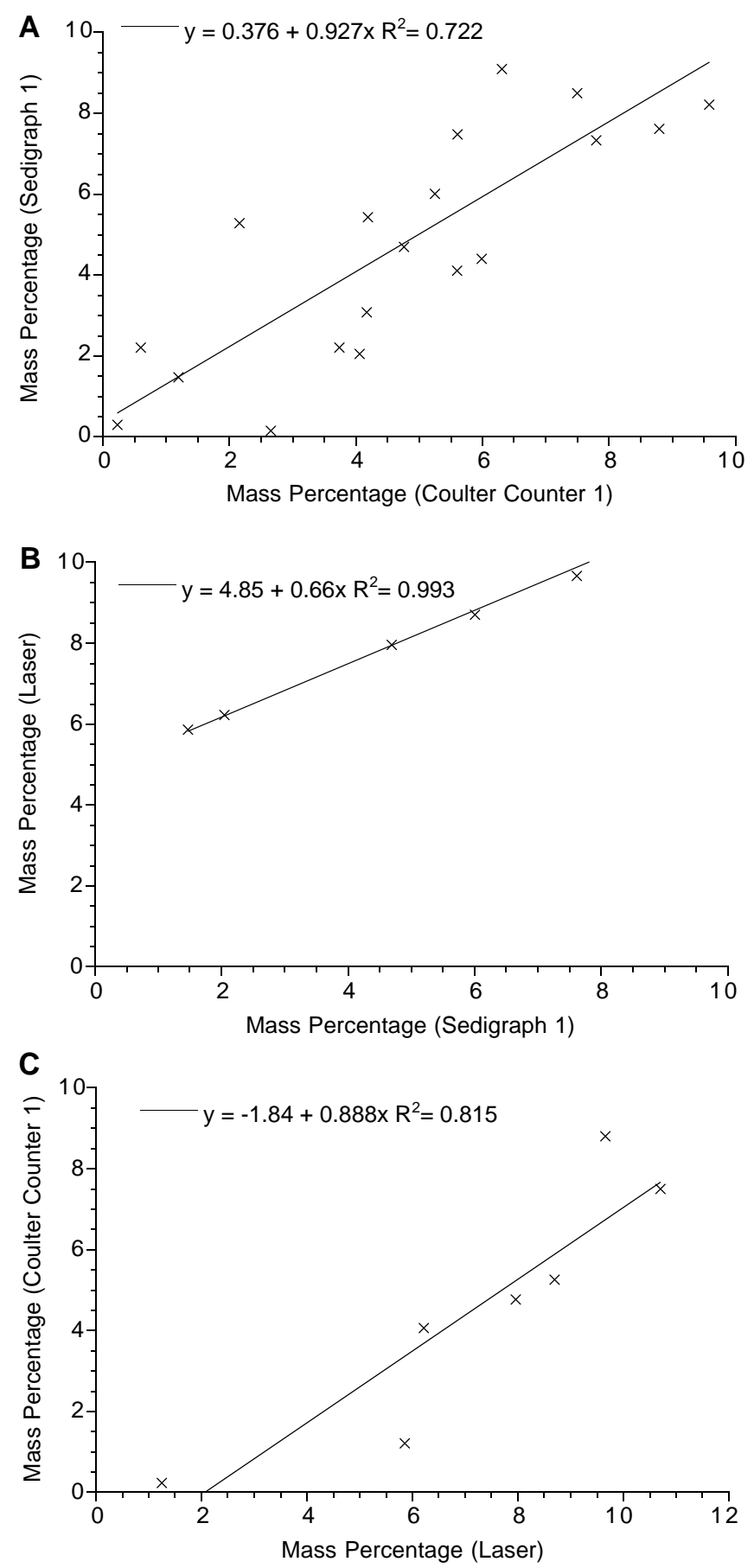

Figure 6. Correlation between the (A) SediGraph and Coulter Counter, (B) Laser and SediGraph, and (C) Coulter Counter and Laser for Sample 155-931B-12X$3,108-110 \mathrm{~cm}$. 